\title{
Fermentation of triacetin and glycerol by Acetobacterium sp. No energy is conserved by acetate excretion*
}

\author{
R. Emde and B. Schink** \\ Fachbereich Biologie-Mikrobiologie, Philipps-Universität, D-3550 Marburg, Federal Republic of Germany
}

\begin{abstract}
Two strains of homoacetogenic bacteria similar to Acetobacterium carbinolicum were enriched and isolated from freshwater and marine sediment samples with triacetin (glycerol triacetylester) as sole carbon and energy source. Also the type strains of $A$. carbinolicum and $A$. woodii were found to be able to grow with triacetin, and to convert it nearly exclusively to acetate. The triacetin-hydrolyzing enzyme was inducible, and was localized in the cytoplasmic fraction of both species at an activity of $0.21-0.26 \mathrm{U} \mathrm{mg}$ protein $^{-1}$. During fermentation of glycerol, varying amounts of 1,3-propranediol were produced which could be kept at a minimum in a glycerol-limited chemostat. Growth yields in batch and continuous culture experiments varied between 9.2 and $10.9 \mathrm{~g} \mathrm{~mol} \mathrm{glycerol}^{-1}$ and 6.5 and $7.6 \mathrm{~g}$ mol triacetin ${ }^{-1}$ with five strains of homoacetogenic bacteria tested. These results indicate that excretion of acetate across the cytoplasmic membrane does not contribute to the energy conservation budget of these homoacetogenic bacteria.
\end{abstract}

Key words: Homoacetogenic bacteria - Acetobacterium $\mathrm{sp}$. - Triacetin - Glycerol fermentation - Transportlinked phosphorylation - Acetate excretion - 1,3-Propanediol

Homoacetogenic bacteria are characterized by their ability to reduce $\mathrm{CO}_{2}$ to acetate using reducing equivalents derived from either inorganic (e.g., $\mathrm{H}_{2}$ ) or organic substrates (Ljungdahl and Wood 1982; Ljungdahl 1983). Several homoacetogens can synthetize acetate from $\mathrm{C}_{1}$ compounds, e.g., formate, methanol, methoxyl groups of aromatic methyl esters (Bache and Pfennig 1981) or N-methyl residues (Eichler and Schink 1984). The pathway of acetate synthesis appears to be basically similar among all homoacetogenic genera, namely, Clostridium (Wieringa 1940; Fontaine et al. 1942; Andreesen et al. 1970; Wiegel et al. 1981; Schink 1984), Acetobacterium (Balch et al. 1977; Braun and Gottschalk 1981; Eichler and Schink 1984), Acetogenium (Leight et al. 1981) and Acetoanaerobium (Sleat et al. 1985). The key enzyme is CO dehydrogenase (acetyl CoA synthase) which catalyzes the condensation of a methyl and a carbonyl

\footnotetext{
* Dedicated to Prof. Dr. Holger W. Jannasch on occasion of his 60 th birthday

** Present address and address for offprint requests: Lehrstuhl Mikrobiologie I, Universität Tübingen, Auf der Morgenstelle 28, D-7400 Tübingen, FRG
}

residue with coenzyme A to acetyl CoA (Wood et al. 1986; Fuchs 1986). However, the way how energy is conserved during autotrophic growth is not yet understood. One ATP can be synthetized by acetate kinase, however, one ATP has also to be spent in the formyl tetrahydrofolate synthetase reaction (Fuchs 1986). The reduction of $\mathrm{CO}_{2}$ to $\mathrm{CO}$ with $\mathrm{H}_{2}$ as electron donor requires energy as well which is provided by the membrane proton motive force (Diekert et al. 1986). It has been suggested that the methylene tetrahydrofolate reductase reaction is coupled to an electron transport reaction. This reaction should establish a proton motive force sufficient to allow an overall energy conservation of $0.5-1$ ATP per acetate produced (Fuchs 1986). However, evidence of such an electron transport-coupled energy conservation is lacking so far.

A different type of energy conservation has been discovered recently. Some lactic acid bacteria appear to couple the efflux of lactic acid with a symport of protons thus establishing a proton motive force by end product excretion (Michels et al. 1979; Otto et al. 1980; ten Brink and Konings 1980). It was suggested that acetate excretion could contribute in a similar manner to energy conservation in homoacetogenic bacteria.

In a study on anaerobic degradation of glycerol acyl esters by anaerobic bacteria, we found recently that homoacetogenic bacteria could be enriched and isolated with glycerol triacetyl ester (triacetin). Provided that the ester-cleaving enzyme is localized in the cytoplasmic space of these bacteria, comparison of growth yields with glycerol or triacetin as substrate should reveal whether acetate excretion can contribute to the overall energy budget of homoacetogenic bacteria. The results of these yield determinations are presented here.

\section{Materials and methods \\ Sources of bacterial strains}

Acetobacterium woodii strain NZva16 was obtained from R. Bache and N. Pfennig, Konstanz. The type strains of Acetobacterium woodii (DSM 1030) and Acetobacterium carbinolicum (DSM 2925) were obtained from the Deutsche Sammlung von Mikroorganismen, Göttingen, FRG.

The following strains were isolated in pure culture from enrichment cultures inoculated with mud samples: strain MrTac1 from marine sediment taken in the Sippewissett marshes west of Woods Hole, MA, USA); strain OyTac1 from sediment taken at the outlet of Oyster Pond close to Woods Hole, MA, USA. 


\section{Media and culture conditions}

Carbonate-buffered, sulfide-reduced mineral medium was prepared as described earlier (Widdel and Pfennig 1981; Schink and Pfennig 1982). The basal medium was autoclaved and the following components were added per liter medium under a $\mathrm{N}_{2} / \mathrm{CO}_{2}(80 \% / 20 \%)$ atmosphere: $2 \mathrm{ml}$ $0.5 \mathrm{M} \mathrm{Na}_{2} \mathrm{~S} \cdot 9 \mathrm{H}_{2} \mathrm{O} ; 1 \mathrm{ml}$ trace element solution SL 10 (Widdel et al. 1983); $1 \mathrm{ml}$ selenite-tungstate solution (Tschech and Pfennig 1984); $30 \mathrm{ml} 1 \mathrm{M} \mathrm{NaHCO}_{3}$ solution; $0.5 \mathrm{ml}$ tenfold concentrated 7-vitamin solution (Pfennig 1978). The $\mathrm{pH}$ was adjusted to 7.2-7.4. For experiments in batch culture, sterile $50 \mathrm{ml}$ screw-cap bottles were filled completely with sterile medium. For experiments in continuous culture, bottles with 101 medium were prepared and kept under a $\mathrm{N}_{2} / \mathrm{CO}_{2}(80 \% / 20 \%)$ atmosphere.

Experiments in continuous culture were performed in an anaerobic chemostat. The $\mathrm{pH}$ was controlled by a Radiometer TT2 titration system (Radiometer, Copenhagen, Denmark). Contamination of the reservoir was prevented by a heat trap. Growth was followed in $1 \mathrm{ml}$ cuvettes in a Zeiss PL4 spectrophotometer at $578 \mathrm{~nm}$. The growth temperature was $28-30^{\circ} \mathrm{C}$ in all cases.

\section{Isolation}

Pure cultures were obtained by repeated application of the agar shake culture method (Pfennig 1978). Tubes were gassed with $\mathrm{N}_{2} / \mathrm{CO}_{2}(80 \% / 20 \%)$ mixture and sealed with butyl rubber stoppers. Purity was checked microscopically and also by growth tests in complex medium (AC medium, Difco Laboratories, Detroit, MI, USA). Gram staining was carried out according to Magee et al. (1975). The KOH-Test (Gregersen 1978) was applied in addition.

\section{Analytical determinations}

Acetate was determined as described earlier (Schink and Pfennig 1982) using a Carlo Erba 6000 Vega Series gaschromatograph equipped with flame ionization detector and a SP 4290 integrator. $5 \mu$ sample was injected directly on a glass column of $2.5 \mathrm{~m}$ length packed with Chromosorb WAW 6 , at a temperature of $140^{\circ} \mathrm{C}$. $\beta$-Hydroxypropionaldehyde was quantified by a colour reaction with dinitrophenyl hydrazine (modified after Yamada and Jakoby 1958). The system was calibrated with sodium pyruvate and propionaldehyde; acetaldehyde and formaldehyde did not form stable complexes. 1,3-propanediol was determined with alcohol dehydrogenase from yeast (Bergmeyer 1974). $50 \mu \mathrm{l} 0.5 \mathrm{M} \mathrm{NAD}, 10 \mu \mathrm{l}$ alcohol dehydrogenase, $0.9 \mathrm{ml}$ buffer and $50 \mu \mathrm{l}$ test solution were incubated for about $4 \mathrm{~h}$ at $37^{\circ} \mathrm{C}$ before evaluation. Oxidation of glycerol as a possible secondary alcohol dehydrogenase-catalyzed reaction could not be detected in control experiments after $4 \mathrm{~h}$ of incubation. The test yielded reproducible results with propanediol concentrations $\geqslant 0.1 \mathrm{mM}$. Glycerol was determined by a standard method (Bergmeyer 1974). Protein was determined in crude cell extracts after Lowry et al. (1951).

\section{Enzyme assays}

The assay of the triacetin-cleaving enzyme was carried out titrimetrically similar to that of pancreas lipase (Bergmeyer et al. 1983) with cell suspensions, crude French press cell
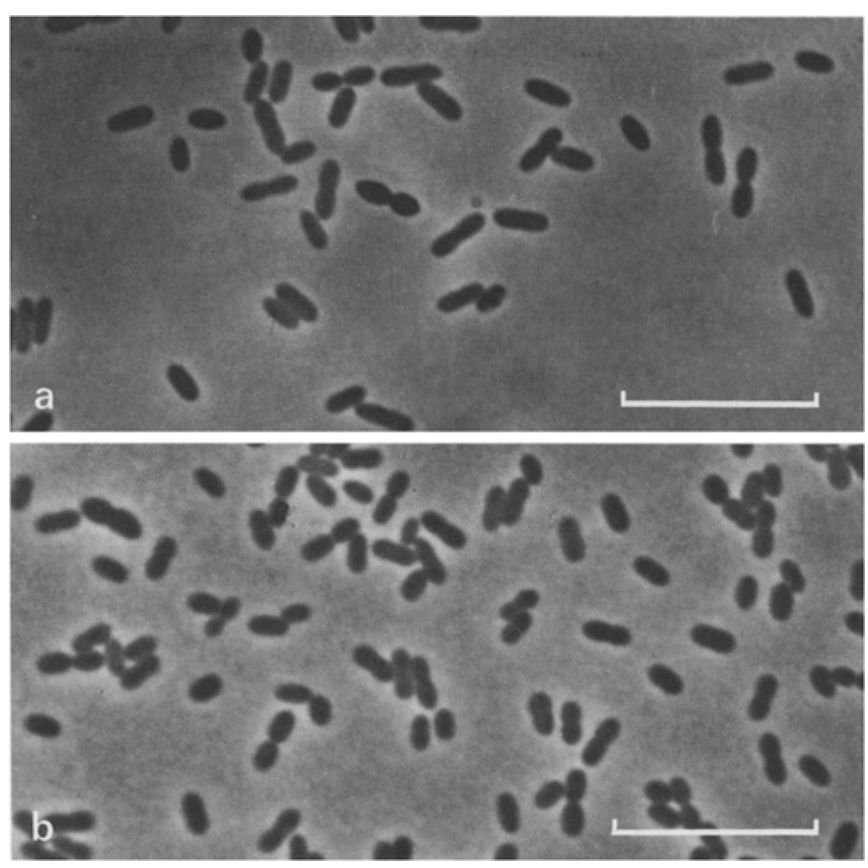

Fig. 1 a, b. Phase contrast photomicrographs of triacetin-fermenting bacterial isolates grown with glycerol. Bar equals $10 \mu \mathrm{m}$ in both panels. a Strain MrTac1, b strain OyTac1

extracts, and protoplast suspensions. $1 \mathrm{ml}$ of e.g. cell suspension was added to $9 \mathrm{ml}$ of $1 \mathrm{mM}$ potassium phosphate buffer, and the $\mathrm{pH}$ was adjusted to 7.0. The reaction was started by adding triacetin to a final concentration of $10 \mathrm{mM}$. The $\mathrm{pH}$ was readjusted continuously with $10 \mathrm{mM}$ $\mathrm{NaOH}$ by a registrating titration system (TT2, Radiometer, Copenhagen, Denmark). Pyruvate kinase was measured by a standard method (Bergmeyer et al. 1983). Protoplasts were prepared by the method of Kaback (1971). Cells were harvested by centrifugation and were resuspended to $1.5 \mathrm{mg}$ dry weight per $\mathrm{ml}$ in $10 \mathrm{mM}$ Tris $/ \mathrm{HCl}$ buffer, $\mathrm{pH} 8.0$ with $10 \mathrm{mM}$ EDTA and $20 \%(\mathrm{w} / \mathrm{v})$ sucrose. The suspension was incubated for $4 \mathrm{~h}$ at $25^{\circ} \mathrm{C}$. Protoplast formation was checked microscopically.

\section{Growth yield determinations}

Determinations of cell yields and of metabolic end products in batch culture were carried out in $50 \mathrm{ml} \mathrm{screw-cap}$ bottles. The substrate concentrations were chosen within the range of proportionality between substrate concentration and cell yield. Substrates were added from freshly prepared stock solutions. Growth yields were calculated via optical densities. Optical densities of outgrown cultures were compared with inoculated blanks without substrate. The relationship between optical density and cell dry weight was determined in growth experiments using $500 \mathrm{ml}$ bottle cultures with growth-limiting concentrations of glycerol. Cell material was harvested by centrifugation, and washed once with $10 \mathrm{mM}$ phosphate buffer, $\mathrm{pH}$ 7.0. The pellet was dried to constant weight at $80^{\circ} \mathrm{C}$. An optical density of $\Delta \mathrm{E}_{578}=0.1$ corresponded to $27.0 \pm 3.0 \mathrm{mg}$ dry weight per liter. For growth yield determinations in continuous culture, samples were taken with a sterile syringe directly out of the culture vessel. After every change of the dilution rate, an adaptation time of $5 \cdot t_{d}$ was allowed to the culture. 
Table 1. Substrates testet for growth of the new triacetin-fermenting strains MrTac1 and OyTac1 and of other homoacetogenic bacteria

\begin{tabular}{|c|c|c|c|c|c|}
\hline Substrate degraded & MrTac1 & OyTac1 & NZVa16 & $\begin{array}{l}\text { Acetobacterium } \\
\text { woodii }^{\mathrm{b}}\end{array}$ & A. carbinolicum ${ }^{\circ}$ \\
\hline Glycerol & + & + & + & $t^{c}$ & + \\
\hline Triacetin & + & + & $+^{d}$ & $t^{d}$ & $+{ }^{\mathbf{d}}$ \\
\hline $\mathrm{H}_{2} / \mathrm{CO}_{2}$ & + & + & + & + & + \\
\hline Formate & + & + & + & + & + \\
\hline Methanol & + & + & + & $+^{a}$ & + \\
\hline 3,4,5-Trimethoxybenzoic acid & + & + & + & $++^{a}$ & + \\
\hline Ethylene glycol & + & + & $-\mathrm{d}$ & + & + \\
\hline Ethanol & + & + & - & - & + \\
\hline Fructose & + & + & + & + & + \\
\hline Glucose & + & + & - & $-^{c}$ & + \\
\hline Lactate & + & + & - & $+d$ & + \\
\hline 2,3-Butanediol & + & + & $-{ }^{d}$ & $+^{\mathrm{c}}$ & + \\
\hline Butanol & + & + & - & - & + \\
\hline
\end{tabular}

a Data from Bache and Pfennig 1981

b Data from Balch et al. 1977

c Data from Eichler and Schink 1984

d Results of the present study

\section{Chemicals}

All chemicals were of reagent grade quality and obtained from Merck, Darmstadt, Fluka, Neu-Ulm, and Sigma, München, FRG. Enzymes were purchased from Boehringer, Mannheim, FRG.

\section{Results}

\section{Enrichment, isolation and characterization}

Enrichment cultures with freshwater and saltwater medium containing $50 \mu \mathrm{l}$ triacetin per $50 \mathrm{ml}$ medium under a $\mathrm{N}_{2} /$ $\mathrm{CO}_{2}$ atmosphere were inoculated with sediment samples from brackish and marine origin. In all cultures, vivid gas formation started after $2-4$ days of incubation. Transfers were made after $1-2$ weeks on the same medium. After $2-$ 3 transfers, rod-shaped bacteria with pointed ends dominated in both enrichment cultures, and methane formation ceased. The predominant bacteria were purified by repeated agar shake dilutions with $10 \mathrm{mM}$ glycerol as substrate. The developing colonies were disc-shaped and pinkish-yellowish in colour. They were transferred into liquid medium and checked for growth with triacetin.

Cells of strain MrTac1 isolated from marine sediment were $1.5-2.7 \cdot 0.8-1.0 \mu \mathrm{m}$ in size. Cells of strain OyTac1 were $1.3-2.5 \cdot 0.8-1.0 \mu \mathrm{m}$ in size. Both had pointed ends and tended to form pairs and short chains similar to Acetobacterium sp. (Fig. 1). During the early stage of cultivation, cells of strain MrTac1 also formed star-like aggregates of cells which sticked together with one cell pole. Spores were not formed. Both strains stained weakly Gram-positive and also behaved Gram-positive in the $\mathrm{KOH}$-Test. They grew with a broad variety of substrates typically also used by homoacetogenic bacteria (Table 1). It appeared justified, therefore, to attribute the new isolates to the genus Acetobacterium, most probably to the species A. carbinolicum.

\section{Utilization of triacetin and glycerol by other homoacetogenic bacteria}

For comparison with the new isolates, also $A$. carbinolicum and two strains of $A$. woodii, strain NZva16 and the type strain DSM 1030, were tested for growth with triacetin. In all cases, growth was observed in batch cultures after an incubation time of 7 days. With $A$. carbinolicum and strain DSM 1030, the growth rates were $0.025 \pm 0.002 \mathrm{~h}^{-1}$ and the doubling times $28 \pm 2.5 \mathrm{~h}$. These growth rates were by far lower than those obtained for growth with glycerol, namely, $0.14 \pm 0.015 \mathrm{~h}^{-1}$. As shown in Table 2, acetate was the major fermentation product, but also 1,3-propanediol and low amounts of an aldehyde, probably $\beta$-hydroxypropionaldehyde, were found. The determined growth yields were $20-40 \%$ higher with glycerol than with triacetin. Due to the high amounts of acetate produced during growth with triacetin, the $\mathrm{pH}$ of these cultures dropped considerably $(<\mathrm{pH} 6.0)$. The acetate concentration had no significant influence on the measured growth yields as proven by control experiments with $5 \mathrm{mM}$ glycerol and background additions of acetate between 10 and $100 \mathrm{mM}$ (results not shown).

\section{Production of 1,3-propanediol}

Although the major end product of glycerol and triacetin fermentation was acetate in all cultures always small amounts of 1,3-propanediol were formed as well. The amount of propanediol produced depended on the culture conditions. It could make up $10-20 \%$ of the total fermentation products in glycerol-grown cultures after an unusually long lag phase or weak growth. In rapidly grown cultures and in most of the cultures grown with triacetin as carbon source, 1,3-propanediol amounted only to about $5 \%$ of total products. Some of the propanediol produced was occasionally converted back to $\beta$-hydroxypropionaldehyde, probably with concomitant $\mathrm{CO}_{2}$ reduction (Fig. 2). In glycerol-limited continuous cultures, the amount of propanediol produced depended on the $\mathrm{pH}$ of the medium in the culture vessel. The production of propanediol was low if the $\mathrm{pH}$ was 7.2 or higher, but rose with lower $\mathrm{pH}$ values (Fig. 3).

\section{Localization and characterization of esterase activity}

For localization of the triacetin-cleaving esterase enzyme, different fractions of cell suspensions, cell homogenates and 
Table 2. Stoichiometry of fermentation and growth yiclds of the new isolates strain MrTac1 and strain OyTac1 and other homoacetogenic bacteria grown with $5 \mathrm{mM}$ glycerol or $5 \mathrm{mM}$ triacetin in batch culture

\begin{tabular}{|c|c|c|c|c|c|c|c|}
\hline & \multirow{2}{*}{$\begin{array}{l}\text { Change in } \\
\text { pH value }\end{array}$} & \multirow{2}{*}{$\begin{array}{l}\triangle \mathrm{OD} \\
\left(\Lambda E_{578}\right)\end{array}$} & \multirow{2}{*}{$\begin{array}{l}\text { Cell dry } \\
\text { weight } \\
\text { formed } \\
\left(\mathrm{mg} \cdot 1^{-1}\right)\end{array}$} & \multicolumn{3}{|c|}{ Products formed (mM) } & \multirow{2}{*}{$\begin{array}{l}\text { Growth } \\
\text { yield } \\
\left(\mathrm{g} \cdot \mathrm{mol}^{-1}\right)\end{array}$} \\
\hline & & & & Propanediol & Aldehyde & Acetate & \\
\hline \multicolumn{8}{|l|}{$5 \mathrm{mM}$ glycerol } \\
\hline Strain MrTac1 & $7.25-6.80$ & 0.170 & 45.9 & 0.70 & 0.085 & 7.54 & 9.18 \\
\hline Strain OyTac1 & $7.20-6.70$ & 0.180 & 48.6 & 0.55 & $<0.05$ & 7.92 & 9.72 \\
\hline Strain NZVa16 & $7.20-6.60$ & 0.190 & 51.3 & 0.30 & $<0.05$ & 8.54 & 10.2 \\
\hline A. woodii & $7.00-6.60$ & 0.180 & 48.6 & 0.40 & 0.055 & 8.41 & 9.72 \\
\hline A. carbinolicum & $7.37-6.78$ & 0.190 & 51.3 & 0.25 & $<0.05$ & 8.34 & 10.2 \\
\hline \multicolumn{8}{|l|}{$5 \mathrm{mM}$ triacetin } \\
\hline Strain MrTac1 & $7.25-5.70$ & 0.140 & 37.8 & 0.20 & $<0.05$ & 22.8 & 7.56 \\
\hline Strain OyTac1 & $7.20-5.80$ & 0.135 & 35.1 & 0.25 & $<0.05$ & 22.5 & 7.29 \\
\hline Strain NZVa16 & $7.20-5.90$ & 0.120 & 32.4 & 0.45 & 0.055 & 20.4 & 6.48 \\
\hline A. woodii & $7.25-5.80$ & 0.130 & 35.1 & 0.15 & $<0.05$ & 23.1 & 7.02 \\
\hline A. carbinolicum & $7.30-5.90$ & 0.135 & 36.4 & 0.30 & $<0.05$ & 22.0 & 7.29 \\
\hline
\end{tabular}

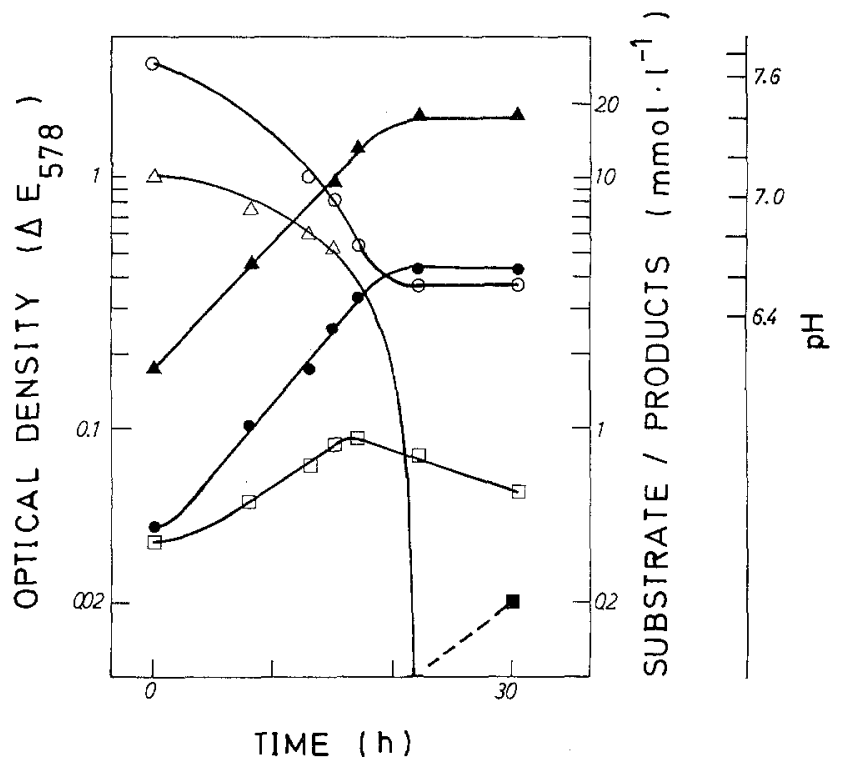

Fig. 2. Growth of Acetobacterium carbinolicum with $10 \mathrm{mM}$ glycerol in batch culture. Optical density, product and substrate concentrations are plotted on a logarithmic scale, the $\mathrm{pH}$ on a linear scale. $(\mathrm{O})$ $\mathrm{pH},(\bullet)$ optical density, $(\triangle)$ glycerol, $(\Delta)$ acetate, $(\square)$ propanediol, (ש) $\beta$-hydroxypropionaldehyde

protoplast suspensions were prepared (Table 3). No esterase activity was found in the spent growth medium. The enzyme activity was associated with protoplasts prepared in the presence and absence of $3 \mathrm{M} \mathrm{KCl}$. After sonication and ultracentrifugation, the whole activity was found in the cytoplasmic supernatant. Comparison with the distribution of pyruvate kinase and total protein content in the various fractions revealed that the esterase is either dissolved in the cytoplasm or is loosely attached to the internal side of the membrane. The measured enzyme activity was $0.21-0.26 \mathrm{U}$ per mg cell protein.

The esterase enzyme reacted only with triacetin, not with tributyrin, ethylvalerate, trilaurin or diolein. Triacetin

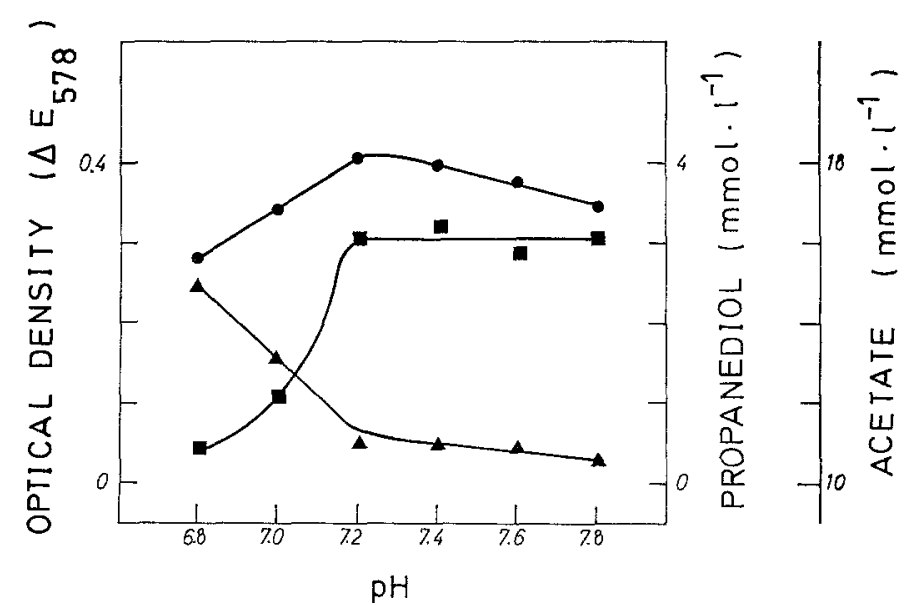

Fig. 3. Dependence of cell density, propanediol and acetate concentration on the medium $\mathrm{pH}$ in continuous culture during growth with $10 \mathrm{mM}$ glycerol. The dilution rate was $0.056 \mathrm{~h}^{-1}$ in all cases. ( Optical density, $(\boldsymbol{\Lambda})$ propanediol, $(\boldsymbol{\square})$ acetate

esterase activity was detected only after growth with triacetin, not in glycerol-grown cells.

\section{Growth yields in continuous culture}

Localization of the esterase inside the cytoplasmic membrane opened the way to check for acetate efflux-dependent energy conservation by possible differences in yields after growth with triacetin or glycerol. To minimize effects of propanediol production and $\mathrm{pH}$ changes, growth yields were measured in $\mathrm{pH}$-controlled continuous culture limited by triacetin or glycerol as substrate. Growth yields were determined at dilution rates of 0.4 and $0.6 \mu_{\max }$ to allow 
Table 3. Distribution of triacetin-cleaving enzyme (esterase), pyruvate kinase, and protein content in various cell fractions of $A$. woodii grown with triacetin. All figures refer to the same initial cell suspension volume. n.d. means not determined

\begin{tabular}{|c|c|c|c|}
\hline & $\begin{array}{l}\text { Esterase activity } \\
\left(\mathbf{U} \cdot \mathrm{ml}^{-1}\right)\end{array}$ & $\begin{array}{l}\text { Pyruvate kinase activity } \\
\left(\mathrm{U} \cdot \mathrm{ml}^{-1}\right)\end{array}$ & $\begin{array}{l}\text { Protein content } \\
\left(\mathrm{mg} \cdot \mathrm{ml}^{-1}\right)\end{array}$ \\
\hline Culture supernatant & $<0.01$ & n.d. & n.d. \\
\hline Cell suspension & $0.33-0.39$ & n.d. & n.d. \\
\hline Cell suspension $+1 \mathrm{mM} \mathrm{KCN}$ & 0.345 & n.d. & n.d. \\
\hline French press cell-free extract & 0.33 & n.d. & n.d. \\
\hline French press cell-free extract $+3 \mathrm{M} \mathrm{KCl}$ & 0.345 & n.d. & n.d. \\
\hline Cytoplasmic fraction & 0.315 & n.d. & n.d. \\
\hline Membrane fraction & 0.003 & n.d. & n.d. \\
\hline Protoplasts & 0.315 & 0.24 & 1.30 \\
\hline Supernatant of protoplasts & 0.03 & 0.03 & 0.15 \\
\hline Protoplasts $+3 \mathrm{M} \mathrm{KCl}$ & 0.24 & 0.18 & 0.97 \\
\hline Supernatant of protoplasts $+3 \mathrm{M} \mathrm{KCl}$ & 0.09 & 0.094 & 0.41 \\
\hline
\end{tabular}

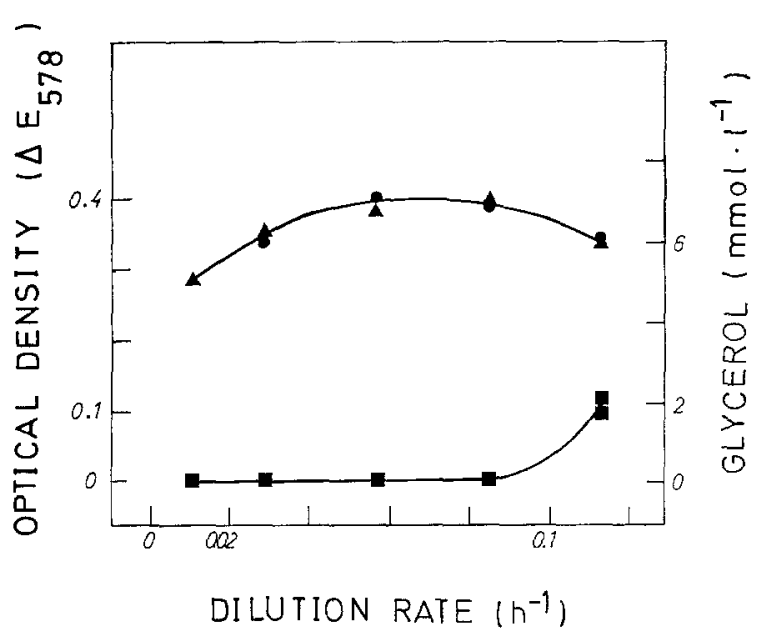

Fig. 4. Cell density and remnant glycerol concentrations during growth of $A$. woodii and $A$. carbinolicum with glycerol at various dilution rates in continuous culture. The $\mathrm{pH}$ was 7.2. (A) $A$. woodii, (O) A. carbinolicum, ( $\mathbf{a}$ ) remnant glycerol

comparison of relative growth rates. As shown in Fig. 4, the highest cell densities were reached with these dilution rates. At higher dilution rates, non-utilized substrate was washed out of the culture vessel. At lower dilution rates, the cell densities decreased as well, probably due to higher relative maintenance energy requirements. The determined growth yields of $A$. woodii and A. carbinolicum (Table 4) were $10.5 \pm 1.0 \mathrm{~g}$ per mol for growth with $10 \mathrm{mM}$ glycerol, and $7.0 \pm 1.0 \mathrm{~g}$ per mol for growth with $10 \mathrm{mM}$ triacetin. In experiments with glycerol at a dilution rate of $0.01 \mathrm{~h}^{-1}$ (corresponding to $0.4 \mu_{\max }$ with triacetin) the growth yield with glycerol decreased to $8.1 \mathrm{~g}$ per mol. The maximum growth rates of $A$. carbinolicum and $A$. woodii in continuous culture $\left(0.152 \mathrm{~h}^{-1}\right.$ with glycerol, and $0.023 \mathrm{~h}^{-1}$ with triacetin) were determined in washout experiments, and were nearly identical with those determined in batch cultures. By plotting $Y^{-1}$ against $D^{-1}$ (Pirt 1965) with the data on glycerol utilization in Fig. 4 and Table 4, the maintenance energy could be calculated to $0.38 \mathrm{mmol}$ per gram and hour.

\section{Discussion \\ Fermentation of glycerol and triacetin}

The homoacetogenic bacteria described in this paper cleaved the ester bonds of triacetin and fermented the glycerol residue. Most of the glycerol was oxidized to acetate, and the electrons released could be used for reduction of dissolved $\mathrm{CO}_{2}$. According to Eichler and Schink (1984):

$$
\begin{gathered}
4 \mathrm{C}_{3} \mathrm{H}_{8} \mathrm{O}_{3}+2 \mathrm{HCO}_{3}^{-} \rightarrow 7 \mathrm{CH}_{3} \mathrm{COO}^{-}+5 \mathrm{H}^{+}+4 \mathrm{H}_{2} \mathrm{O} \\
\Delta \mathrm{G}_{0}^{\prime}=-151.7 \mathrm{~kJ} \mathrm{~mol}^{-1} .
\end{gathered}
$$

However, significant amounts of 1,3-propanediol and traces of $\beta$-hydroxypropionaldehyde were formed indicating that part of the glycerol provided was reduced via glycerol dehydratase and propanediol dehydrogenase (Lin 1976). This reaction sequence is used by several fermenting bacteria, e.g. Lactobacillus, Klebsiella, and Citrobacter as reductive branch of glycerol fermentation (Braak 1928; Abeles et al. 1960; Schütz and Radler 1983). For a homoacetogenic bacterium, propanediol formation appears to be a waste of fermentation substrate and of energetically valuable electrons.

Homoacetogenic bacteria were only recently found to have unusual degradative capacities, such as cleavage of phenyl methyl linkages (Bache and Pfennig 1981) or Nmethyl bonds (Eichler and Schink 1984). The present study provides evidence that these versatile anaerobes are also able to hydrolyze glycerol acetylesters. The enzyme catalyzing this reaction was found to be localized inside the cytoplasm. In this point it differs basically from lipases, e.g. the lipase of Anaerovibrio lipolytica which is excreted into the extracellular medium (Henderson 1968, 1971).

The specific activity was low $(0.21-0.26 \mathrm{U} \cdot \mathrm{mg}$ protein $^{-1}$ ), and just sufficient to allow growth with this substrate at the observed low growth rates $\left(0.025 \mathrm{~h}^{-1}\right.$ versus $0.14 \mathrm{~h}^{-1}$ with glycerol). The observation that enzyme activity was found only in cultures grown with triacetin and not in cultures grown with glycerol leads to the conclusion that this enzyme is inducible. However, it remains unclear at the moment what the physiological function of this enzyme is in nature.

Contrary to the lipase of Anaerovibrio lipolytica, no long chain fatty acid esters such as trilaurin or diolein were cleaved. This suggests that the enzyme is not a lipase but belongs to the group of carboxylesterases. Some members 
Table 4. Stoichiometry of fermentation and growth yields of $A$. woodii and $A$. carbinolicum during growth with $10 \mathrm{mM}$ glycerol or $10 \mathrm{mM}$ triacetin in continuous culture at various dilution rates. The $\mathrm{pH}$ in the culture vessel was 7.2. The concentration of $\beta$-hydroxypropionaldehyde was always lower than $0.05 \mathrm{mM}$

\begin{tabular}{|c|c|c|c|c|c|c|c|}
\hline \multirow{2}{*}{$\begin{array}{l}\text { Dilution } \\
\text { rate } \\
\left(\mathrm{h}^{-1}\right)\end{array}$} & \multirow{2}{*}{$\begin{array}{l}\text { Optical } \\
\text { density } \\
\left(\triangle E_{578}\right)\end{array}$} & \multirow{2}{*}{$\begin{array}{l}\text { Cell dry } \\
\text { weight } \\
\text { formed } \\
\left(\mathrm{mg} \cdot 1^{-1}\right)\end{array}$} & \multirow{2}{*}{$\begin{array}{l}\text { Glycerol } \\
\text { concentration } \\
\text { provided } \\
(\mathrm{mM})\end{array}$} & \multirow{2}{*}{$\begin{array}{l}\text { Triacetin } \\
\text { concentration } \\
\text { provided } \\
(\mathrm{mM})\end{array}$} & \multicolumn{2}{|c|}{ Products formed (mM) } & \multirow{2}{*}{$\begin{array}{l}\text { Growth } \\
\text { yield } \\
\left(\mathrm{g} \cdot \mathrm{mol}^{-1}\right)\end{array}$} \\
\hline & & & & & Propanediol & Acetate & \\
\hline \multicolumn{8}{|l|}{ A. woodii } \\
\hline 0.084 & 0.405 & 109 & 10 & & 0.35 & 16.0 & 10.9 \\
\hline 0.056 & 0.385 & 103 & 10 & & 0.30 & 14.4 & 10.3 \\
\hline 0.010 & 0.300 & 81.0 & 10 & & 0.30 & 15.6 & 8.10 \\
\hline 0.015 & 0.255 & 68.8 & & 10 & 0.35 & 46.1 & 6.88 \\
\hline 0.010 & 0.270 & 72.9 & & 10 & 0.20 & 47.2 & 7.29 \\
\hline \multicolumn{8}{|c|}{ A. carbinolicum } \\
\hline 0.084 & 0.395 & 106 & 10 & & 0.45 & 15.6 & 10.6 \\
\hline 0.056 & 0.405 & 109 & 10 & & 0.35 & 16.1 & 10.9 \\
\hline 0.015 & 0.260 & 70.2 & & 10 & 0.35 & 47.1 & 7.02 \\
\hline 0.010 & 0.275 & 74.2 & & 10 & 0.10 & 47.5 & 7.42 \\
\hline 0.005 & 0.230 & 62.1 & & 10 & 0.65 & 44.5 & 6.21 \\
\hline
\end{tabular}

of this group such as acetylesterase cleave triacetin and exhibit their highest activity generally with acetic acid esters. It has to be assumed that the triacetin-hydrolyzing enzyme described here is an acetylesterase of this kind (Bergmann et al. 1957; Bergmann and Rimon 1960).

\section{Comparison of growth yields during growth with glycerol and with triacetin}

The fermentation of glycerol and $\mathrm{CO}_{2}$ to acetate as sole product is an exergonic process with a free energy change of $-151.7 \mathrm{~kJ}$ per mol. If one assumes that about $70-80 \mathrm{~kJ}$ are necessary to irreversibly synthetize $1 \mathrm{~mol}$ ATP (Thauer et al. 1977), glycerol conversion to acetate could allow synthesis of about 2 mol ATP per mol glycerol. 2 ATP can be synthetized via substrate-linked phosphorylation in the Embden-Meyerhof pathway and the subsequent acetate kinase reaction, and a further fraction of an ATP could be formed during $\mathrm{CO}_{2}$ reduction to acetate. The growth yield values determined in the present study in batch and continuous culture experiments were in the range of 9.2 to $10.9 \mathrm{~g}$ per mol glycerol. Correcting for the maintenance energy losses (Pirt 1975, 1982) a theoretical maximum growth yield of $11.4 \mathrm{~g}$ per mol glycerol can be calculated.

From the above assumptions, a $Y_{\text {ATP }}$ value of about $5 \mathrm{~g}$ can be calculated which is at the lowermost rank of $Y_{\text {ATP }}$ values reported for other bacteria (Stouthamer 1979) but agrees with those values measured with homoacetogenic bacteria on other substrates (Tschech and Pfennig 1984; Eichler and Schink 1984).

The growth yields with triacetin as substrate were generally lower than with glycerol, namely, 6.5-7.6 g per mol. Since growth with this substrate was considerably slower than with glycerol, correction for maintenance energy losses according to the Pirt equation leads to a theoretical maximum growth yield of $10.2 \mathrm{~g}$ per mol triacetin which is about the same as the value calculated for glycerol above. If Acetobacterium was grown with glycerol at the same low growth rate as with triacetin, the growth yield $(8.1 \mathrm{~g}$ per mol) approached that obtained with triacetin as well. Thus, it appears evident that growth yields with triacetin never exceeded those obtained with glycerol, but that both were nearly identical if compared under similar growth conditions. To mention this appears necessary because the reliability of the Pirt equation has been questioned repeatedly (e.g. van Verseveld et al. 1984).

Since the triacetin-cleaving enzyme was found in the cytoplasmic space of the cell the results of the present growth yield determinations provide evidence that the Acetobacterium strains studied do not conserve energy by ATP synthesis via a transport-coupled phosphorylation system. This differs from lactate export in lactic acid bacteria for which a transport-coupled phosphorylation system appears to be well established (Michels et al. 1979; Otto et al. 1980; ten Brink and Konings 1980). It can be argued that due to the different $\mathrm{pK}$ values of acetate and lactate (4.8 versus 3.8 ) the ratio of nondissociated over deprotonated acid molecules is at a given $\mathrm{pH}$ about 10 times higher with acetate than with lactate. Back diffusion of uncharged acetic acid molecules would have an uncoupling (Baronofsky et al. 1984) rather than an energy-conserving effect in such a system if a proton symport-coupled acetate export system analogous to the lactate export system would be operating in homoacetogenic and other acetate-producing bacteria.

Acknowledgements. The idea to this study arose during the summer course on microbial ecology in Woods Hole in 1985 in which B. S. was involved as a staff member, together with Ralph S. Wolfe and Peter Greenberg. The authors acknowledge stimulating discussions as well with Rudolf K. Thauer, Marburg, on microbial energetics.

\section{References}

Abeles RH, Brownstein AM, Randes CH (1960) $\beta$-Hydroxy-propionaldehyde, an intermediate in the formation of 1,3-propanediol by Aerobacter aerogenes. Biochim Biophys Acta $41: 530-531$

Andreesen JR, Gottschalk G, Schlegel HG (1970) Clostridium formicoaceticum nov. spec. Isolation, description and distinction from $C$. aceticum and $C$. thermoaceticum. Arch Microbiol $72: 154-174$

Bache R, Pfennig N (1981) Selective isolation of Acetobacterium woodii on methoxylated aromatic acids and determination of growth yields. Arch Microbiol 130:255-261 
Balch WE, Schoberth S, Tanner RS, Wolfe RS (1977) Acetobacterium, a new genus of hydrogen-oxidizing, carbon dioxidereducing, anaerobic bacteria. Int J Syst Bacteriol 27:355-361

Baronofsky JJ, Schreurs WJA, Kashket ER (1984) Uncoupling by acetic acid limits growth of and acetogenesis by Clostridium thermoaceticum. Appl Environ Microbiol 48:1134-1139

Bergmann F, Rimon S (1960) Fractionation of c-esterase from the hog's kidney extract. Biochem J 77:209-214

Bergmann F, Segal R, Rimon S (1957) A new type of esterase in hog-kidney extract. Biochem J 67:481-486

Bergmeyer HU (1974) Methoden der enzymatischen Analyse, 3. edn. Verlag Chemie, Weinheim/Bergstraße

Bergmeyer HU, Bergmeyer J, Grasse M (chief editor) (1983) Methods of enzymatic analysis, 3. edn. Verlag Chemie, Weinheim Deerfield Beach Basel

Braak HR (1928) Onderzoeking over vergisting van glycerine. Diss Univ. of Delft, Netherlands

Braun K, Gottschalk G (1981) Effect of molecular hydrogen and carbon dioxide on chemo-organotrophic growth of Acetobacterium woodii and Clostridium aceticum. Arch Microbiol 128:294-298

Brink B ten, Konings WN (1980) Generation of an electrochemical proton gradient by lactate efflux in membrane vesicles of Escherichia coli. Eur J Biochem 111:59-66

Diekert G, Schrader E, Harder W (1986) Energetics of CO oxidation in cell suspensions of Acetobacterium woodii. Arch Microbiol $144: 386-392$

Eichler B, Schink B (1984) Oxidation of primary aliphatic alcohols by Acetobacterium carbinolicum sp. nov., a homoacetogenic anaerobe. Arch Microbiol 140:147-152

Fontaine F, Peterson WH, McCoy E, Johnson MJ, Ritter GJ (1942) A new type of glucose fermentation by Clostridium thermoaceticum, n. sp. J Bacteriol 43:701-715

Fuchs $\mathrm{G}$ (1986) $\mathrm{CO}_{2}$ fixation in acetogenic bacteria: variations on a theme. FEMS Microbiol Rev 39:181-213

Gregersen T (1978) Rapid method for distinction of Gram-negative from Gram-positive bacteria. Eur J Appl Microbiol Biotechnol $5: 123-127$

Henderson C (1968) A study of the lipase of Anaerovibrio lipolytica, a rumen bacterium. $\mathrm{Ph} \mathrm{D}$ Thesis, Univ of Aberdeen

Henderson C (1971) A study of the lipase produced by Anaerovibrio lipolytica, a rumen bacterium. J Gen Microbiol 65:81-89

Kaback HR (1971) Enzyme purification and related techniques. In: Jacoby WB (ed) Methods in enzymology, vol 22. Academic Press, New York San Francisco London, pp 99-108

Leigh JA, Mayer F, Wolfe RS (1981) Acetogenium kivui, a new thermophilic hydrogen-oxidizing acetogenic bacterium. Arch Microbiol 129:275-280

Lin ECC (1976) Glycerol-dissimilation and its regulation in bacteria. Ann Rev Microbiol 30:535-578

Ljungdahl LG (1983) Formation of acetate using homoacetate fermenting anaerobic bacteria. In: Wise DL (ed) Organic chemicals from biomass. Benjamin Cummins Publ Co, Menlo Park Ca, pp 219-248

Ljungdahl LG, Wood HG (1982) Acetate biosynthesis. In: Dolphin D (ed) Vitamin $B_{12}$. Wiley, New York, pp 165-202

Lowry OH, Rosebrough NJ, Farr AL, Randall RJ (1951) Protein measurement with the Folin phenol reagent. J Biol Chem 193: $265-275$

Magee CM, Rodeheaver G, Edgerton MT, Edlich RF (1975) A more reliable Gram staining technic for diagnosis of surgical infections. Am J Surgery 130:341-346

Michels PAM, Michels JPJ, Boonstra J, Konings WN (1979) Generation of an electrochemical proton gradient in bacteria by the excretion of metabolic end products. FEMS Microbiol Lett $5: 357-364$
Otto R, Sonnenberg ASM, Veldkamp H, Konings WN (1980) Generation of an electrochemical proton gradient in Streptococcus cremoris by lactate efflux. Proc Nat Acad Sci USA 77:55025506

Pfennig N (1978) Rhodocyclus purpureus gen. nov. and sp. nov, a ring shaped, vitamin $B_{12}$-requiring member of the family Rhodospirillaceae. Int J Syst Bacteriol 28:283-288

Pirt SJ (1965) The maintenance energy of bacteria in growing cultures. Proc Roy Soc B 163:224-231

Pirt SJ (1975) Principles of microbe and cell cultivation. Blackwell Scientific, Oxford

Pirt SJ (1982) Maintenance energy, a general model for energylimited and energy-sufficient growth. Arch Microbiol 133: $300-302$

Schink B (1984) Clostridium magnum sp. nov., a non-autotrophic homoacetogenic bacterium. Arch Microbiol 137:250-255

Schink B, Pfennig N (1982) Fermentation of trihydroxybenzenes by Pelobacter acidigallici gen. nov. sp. nov., a new strictly anaerobic, non-sporeforming bacterium. Arch Microbiol 133:195201

Schütz H, Radler F (1983) Anaerobic reduction of glycerol to propanediol-1,3 by Lactobacillus brevis and Lactobacillus buchneri. Syst Appl Microbiol 5:169-178

Sleat R, Mah RA, Robinson R (1985) Acetoanaerobium noterae gen. nov. sp. nov., an anaerobic bacterium that forms acetate from $\mathrm{H}_{2}$ and $\mathrm{CO}_{2}$. Int $\mathbf{J}$ Syst Bacteriol 35:10-15

Stouthamer AH (1979) The search for correlation between theoretical and experimental growth yields. Int Rev Biochem Microbiol Biochem 21:1-47

Thauer RK, Jungermann K, Decker K (1977) Energy conservation in chemotrophic anaerobic bacteria. Bacteriol Rev 41:100180

Tschech A, Pfennig N (1984) Growth yield increase linked to caffeate reduction in Acetobacterium woodii. Arch Microbiol 137:163-167

Verseveld HW van, Chesbro WR, Braster M, Stouthamer AH (1984) Eubacteria have 3 growth modes keyed to nutrient flow. Consequences for the concept of maintenance and maximal growth yield. Arch Microbiol 137:176-184

Widdel F, Pfennig N (1981) Studies on dissimilatory sulfate-reducing bacteria that decompose fatty acids. I. Isolation of new sulfate-reducing bacteria enriched with acetate from saline environments. Description of Desulfobacter postgatei gen. nov. sp. nov., Arch Microbiol 129:395-400

Widdel F, Kohring GW, Mayer F (1983) Studies on dissimilatory sulfate-reducing bacteria that decompose fatty acids. III. Characterization of the filamentous gliding Desulfonema limicola gen. nov. sp. nov., and Desulfonema magnum sp. nov. Arch Microbiol 134:286-294

Wiegel J, Braun M, Gottschalk G (1981) Clostridium thermoautotrophicum species novum, a thermophile producing acetate from molecular hydrogen and carbon dioxide. Curr Microbiol $5: 255-260$

Wieringa KT (1940) The formation of acetic acid from carbon dioxide and hydrogen by anaerobic spore forming bacteria. Antonie van Leuwenhoek 7 Microbiol Serol 6:251 - 262

Wood HG, Ragsdale SW, Pezacka E (1986) The acetyl-CoA pathway of autotrophic growth. FEMS Microbiol Rev $39: 345-362$

Yamada EW, Jakoby WB (1958) Enzymatic utilization of acetylenic compounds. I. An enzyme converting acetylenedicarboxylic acid to pyruvate. J Biol Chem 233:706-711

Received June 1, 1987/Accepted September 1, 1987 